\title{
Coordination as a Political Problem in Coordinated Market Economies ${ }^{1}$
}

\section{KATHLEEN THELEN* and IKUO KUME**}

The purpose of this article is to explore the political dynamics of employer coordination in three well-known "coordinated market economies." We examine differences in how employer coordination has been organized in Sweden, Germany, and Japan in the area of industrial relations, and we examine the extent to which such coordination represents a self-sustaining equilibrium, as some of the most influential treatments suggest. To preview the findings, we argue that precisely the intensification of cooperation between labor and management in some firms and industries (that the "varieties of capitalism" literature correctly emphasizes) has paradoxically had deeply destabilizing collateral effects that have undermined or are undermining these systems as they were traditionally constituted. All three cases are characterized not so much by a full-blown breakdown of coordination so much as a very significant reconfiguration of the terms and scope of such coordination. Specifically, all three countries feature the emergence of new or intensified forms of dualism-different in each case based on different starting points - in which continued coordination within a smaller core has in some ways been underwritten through the breaking off of other, more peripheral, firms and workers.

\section{Introduction}

A relatively new and highly influential line of thought in the literature on the political economy of advanced capitalism draws attention to the central role of employer coordination in the construction and maintenance of distinctive "varieties of capitalism" (see, especially, Hall and Soskice 2001). Whereas much of the earlier literature on democratic corporatism cited the central importance of labor strength and centralization to a variety of institutional and macroeconomic outcomes, this newer body of work argues that the capacity of employers to coordinate among themselves is what holds the key to understanding a range of outcomes that in the past were associated with corporatism (Soskice 1990).

The varieties of capitalism literature has provided a powerful corrective to a previous wave of theorizing that saw traditional labor institu-

${ }^{*}$ Northwestern University

**Waseda University

Governance: An International Journal of Policy, Administration, and Institutions, Vol. 19, No. 1, January 2006 (pp. 11-42).

(C) 2006 The Authors

Journal compilation (c) 2006 Blackwell Publishing, 350 Main St., Malden, MA 02148, USA, and 9600 Garsington Road, Oxford, OX4 2DQ, UK. ISSN 0952-1895 
tions, especially in "coordinated market economies," as extremely fragile in the face of neoliberal ideology and more volatile international markets since the 1980s. ${ }^{2}$ Much of the previous literature was premised on the idea that globalization would push all countries toward neoliberalism and deregulation, encouraging firms to lower labor costs and increase labor market flexibility while undermining the power of unions to prevent these (Kapstein 1996; Katz and Darbishire 1999; Martin and Ross 1999). However, convergence theories predicting a uniform slide into deregulation have not been borne out (Berger and Dore 1996; Boyer and Hollingsworth 1997; Ferner and Hyman 1998; Wallerstein, Golden, and Lange 1997; Zysman 1996). Moreover, theories that attributed the resilience of traditional bargaining institutions in some countries to successful union defense do not provide much purchase, either, on observed cross-national patterns of stability and change (e.g., Katz 1993; Turner 1998).

The varieties of capitalism (VOC) perspective is premised on a distinction between "coordinated" versus "liberal" market economies, which points to differences in the extent to which employers can coordinate among themselves to achieve joint gains. ${ }^{3}$ These differences are expressed in different clusters of institutions in the two types of political economies-including particular kinds of financial institutions, collective bargaining institutions, vocational training institutions, even welfare state institutions-that in turn support distinctive types of employer strategies in the market (see also Ebbinghaus and Manow 2001). Because of their divergent arrangements, the two types of political economies are associated with efficiency in the production of different sets of goods (Hall and Soskice 2001, 36-44).

The VOC literature suggests that-far from convergence-we should see continued diversity and indeed even stronger divergence between the liberal market economies and coordinated market economies (see also Iversen, Pontusson, and Soskice 2000; Kitschelt et al. 1999; Thelen 2001). Rather than universally embracing deregulation, employers in the developed democracies will seek to confront new market challenges by building on and deepening previous sources of comparative institutional advantage. Thus, while employers in the United States and United Kingdom may well seek deregulation, employers in countries such as Germany, Sweden, and Japan will hold to traditional arrangements, because the strategies they have developed in the market rely on a high degree of labor cooperation, strong worker investment in skill acquisition, and peaceful plant relations-all of these being elements that traditional labor relations institutions and practices provide. ${ }^{4}$

In short, and in contrast to convergence or even "common trajectory" theories (Pontusson 2000), the VOC literature, if anything, predicts heightened divergence across systems. The argument above all draws attention to how employers themselves have become invested in various institutions (including centralized wage bargaining in some of Europe's corporatist democracies, and also traditional industrial relations practices 
such as lifetime employment and seniority wages in Japan's coordinated market economy). The basic logic is that, because employers have organized their competitive strategies around these institutions, and especially because these institutions now act as crucial supports for these strategies, employers will not abandon them in the face of new market pressures (Thelen 2000). To the extent that the theory sees employers as supportive of, and indeed dependent on, existing institutions, all feedback within the system is, so to speak, positive and supports the maintenance of traditional institutions.

\section{Problems with the VOC Framework and the Concept of Employer Coordination in Particular}

In general, we think that the emphasis in the varieties of capitalism literature on employers' own continuing interest in traditional labor relations institutions in the coordinated market economies does provide a better explanation of the surprising resilience of such institutions in the face of new competitive pressures than rival theories that attribute these outcomes to "institutional inertia" or successful union defense (Thelen 2001, 2002; Thelen and Kume 1999).

However, as an empirical matter, we know there have been and in some cases continue to be rather significant tensions at work in traditional industrial relations institutions in coordinated market economies, including those that are the focus of this article, Sweden, Germany, and Japan. In Sweden, tensions were already high in the 1980s but came to a head in 1990 when the national confederation of Swedish employers (Svenska Arbetsgivareföreningen [SAF]) withdrew entirely from the tripartite structures that had traditionally defined that country's particular (and particularly centralized) version of coordination. In Germany, serious strains in traditional industrial relations institutions have been evident, especially since the 1990s as declining union membership and problems within key employer associations have resulted in a noticeable drop in collective bargaining coverage in some core industries. Finally, in Japan, recent years have witnessed some well-publicized cases of retreat by key employers from traditional practices including, above all, seniority wages and, to a lesser extent, commitment to lifetime employment.

Such tensions and changes in these institutions are enormously difficult to get a handle on if we stay within the varieties of capitalism framework, and we think that a part of the problem has to do with the key concept of "coordination." There are several related issues (for elaboration, see Thelen 2002). First, employer coordination is a quite apolitical and, in practice, often essentially bimodal concept that enters into the analysis as a "condition" or characteristic that some countries have and others lack. Second, and related to this, much writing in the VOC literature (including, self-critically, Thelen 2001) is based on a very stylized and highly composite (national-level) picture of employer interests. Thus, in 
this literature, employers (as a whole-within a given country) in coordinated market economies are seen as "invested" in various institutions (wage bargaining institutions, for instance), and from this it follows that they will have an interest in maintaining these institutions-among other things - as the site within which they can continue to coordinate among themselves, to the benefit of all.

In what follows, we examine employer coordination as a political problem in Sweden, Germany, and Japan in the contemporary period. Rather than looking at employer interests from the perspective of a highly composite view, we focus on the problem of sustaining employer coordination in a context in which the interests of various segments of capital (and for that matter, labor) are diverging in the face of new market conditions, and where coordination is sustained in part by a political settlement among them (often also the exercise of power or dominance of some firms or industries over others). Contemporary market conditions do not just activate new conflicts between labor and capital (as is widely known and theorized); they also activate new tensions and strains among firms and industries that are differently situated in domestic and international markets. Rather than thinking of coordination as a "thing" or "state of affairs" that whole countries either have or do not have, we think it is much more useful to conceive of coordination as a political process and something that is not at all self-sustaining but in fact has to be constantly nurtured and "patched up," and sometimes renegotiated entirely.

By disaggregating "employers" (and "labor") and by adopting a more explicitly political approach to the problem of "coordination," we are able to embrace and incorporate some of the core insights of the VOC perspective, especially regarding the continuing interests of some employers in traditional industrial relations institutions and practices. At the same time, we address the tensions in these institutions that the VOC literature has tended to ignore or minimize. In contrast to much VOC-based theorizing, which sees all feedback in these systems as positive and stabilizing, we argue that precisely the intensification of cooperation between labor and management in some firms and industries (that the VOC literature correctly emphasizes) has paradoxically had deeply destabilizing collateral effects that have undermined or are undermining these systems as they were traditionally constituted. The next sections lay out the dynamics for Sweden, Germany, and Japan, respectively.

\section{Coordination as a Political Process: Case Studies}

\section{Sweden}

Among the coordinated market economies, Sweden was notable for the high level of centralization that traditionally characterized industrial relations there. Between 1956 and 1983, the broad parameters for wage settlements covering most of the economy were set at the national level 
in peak negotiations between the main (blue-collar) union confederation, Landsorganisationen (LO), and the national confederation of Swedish employers, SAF (see, e.g., Martin 1991). This system broke down, in a halting way in the 1980s, but decisively and apparently irreversibly in the early 1990s when SAF eliminated its own bargaining unit (leaving its counterpart on the union side, LO, no one to negotiate with) (Pontusson and Swenson 1996, 224). Michael Wallerstein and Miriam Golden (1997) single out Sweden as one of two cases-along with Britain - of significant institutional change in collective bargaining in the 1980s and early 1990s.

Developments since the early 1990s do not, however, point to a full breakdown of all coordination and a free fall into decentralization; instead, wage bargaining has re-equilibrated on the basis of a very different pattern of coordination. Currently, the Swedish system is characterized by highly coordinated bargaining across industries within the export sector (including much stronger cooperation than ever before between unions organizing blue-collar and white-collar workers)—combined, however, with much looser coordination between the exposed and sheltered sectors of the economy. Sweden's touted system of solidaristic wage bargaining, which had resulted in a significant compression of wages across the economy, was a main casualty in the reorganization, as reflected in growing wage differentiation within and especially between these broad bargaining clusters (Hibbs and Locking 2000).

The breakdown of the previous model of bargaining has been analyzed by others and need not be recounted at length here (Martin 1991; Pontusson and Swenson 1996). Swedish employers had originally agreed to centralized bargaining as a way of ensuring wage moderation; however, over time the system had come to deliver wage settlements that were both rigid and highly inflationary (Martin 1991, 33). Centralized bargaining up to the 1960s was associated with a form of wage solidarism that equalized pay across industries and plants ("equal pay for equal work" regardless of a firm's profitability). This was consistent with and in fact promoted an ongoing shift in resources (including labor) out of declining and into more competitive industries. However, by the late 1960s "wage solidarity took a more radically egalitarian turn, ... in the direction of compressing relative wages more or less across the board" (Hibbs and Locking 2000, $759,762)$. Specifically, provisions negotiated in central bargaining began to compensate low-paid groups (public sector and low-skilled industrial workers) for wage drift enjoyed by skilled industrial workers (Martin 1991, 35; Pontusson and Swenson 1996, 232-233). These provisions had highly inflationary consequences, fueling a chronic, institutionalized ratcheting up of wages (Elvander 1997, 13; Martin 1991, 35).

The negative effects of these developments were felt especially intensely in the engineering industry, and the employer association in that sector (Verkstadsföreningen, or VF; later Verstadsindustrier, or VI) led the drive for bargaining decentralization in the 1980s and 1990s. The 
VF/VI had opposed the new wage-leveling clauses cited above from early on (Martin 1991, 85), but its appeals to oppose them found no resonance among employers in other industries that were less affected. In the absence of movement on these issues in national negotiations, the VI in 1983 decided to go it alone and withdrew from traditional peak (confederal) bargaining altogether, striking a separate deal with the metalworkers' union, Metall. This dealt a decisive blow to the traditional nationally coordinated system, one from which that system never really recovered. ${ }^{5}$

While it is clear that employers (and specifically employers in the engineering industry) led the charge against the old system, studies have revealed that what has sometimes been coded as a neoliberal employer offensive against the traditional Swedish system is better characterized as a cross-class realignment that brought together employers and unions in the export sectors (but especially in the engineering industry), at the expense of traditional, more encompassing forms of coordination and solidarity (e.g., especially Iversen 1996). First, and as Jonas Pontusson and Peter Swenson $(1996,228)$ emphasize, the initial break with centralized bargaining (in 1983) was not accomplished through conflict, but instead took the form of a deal in which the VF offered the metalworkers' union (Metall) a wage increase above what the union had demanded, but in exchange for decoupling negotiations from the peak bargain and eliminating contractual provisions that compressed the wages of skilled and unskilled workers.

A wage offer that exceeded the union's own demand would in any event have been hard to decline. However, in addition, Metall had also developed its own reasons for disliking aspects of the wage system as traditionally constituted and as practiced under the new (expanded) terms of wage solidarity. Among other things, engineering workers had come to think of public-sector workers as "pay parasites" and resented their ability to free-ride on the productivity gains in engineering through the compensation clauses mentioned above (Pontusson and Swenson 1996, 234). Beyond this, the interoccupational leveling clauses (between skilled and unskilled workers) had also become a problem for Metall. Technological changes in engineering had blurred the line between skilled blue-collar and white-collar occupations, so that high-skill metalworkers often found themselves working in jobs very similar to that of members of the separate white-collar union, Svenska Industritjänstemannaförbundet (SIF), but-because of wage compression within Metall—at a much lower rate of pay (Mahon 1991; Martin 1991, 36).

VI's break with the system of peak-level bargaining ushered in a period of uncertainty, characterized by demands on the part of some influential firms like Volvo, Ericsson, and ABB for further decentralization to the plant level, but with other firms and sectors advocating the more intermediate solution of industry-level negotiations. Full decentralization to the plant level proved unrealistic (see, e.g., Thelen 2001), and SAF's dis- 
mantling of its own bargaining apparatus in 1990 of course made a return to national-level bargaining along the old lines impossible. It therefore looked as though the settling point would be industry-level bargaining, without any interindustry coordination. However, the 1995 bargaining round was crucial in highlighting the potential pitfalls (for employers) of a lack of cooperation across industries within private sector manufacturing. In that year, a very high settlement in the (then-booming) paper and pulp industry disrupted negotiations in the metalworking industry, leading to costly work stoppages and, ultimately, a higher settlement (see Elvander 1997, 49-50; Kjellberg 1998; also Thelen 2001 for a more extended version). Employers continued to oppose vociferously any recentralization of national bargaining under the auspices of the $\mathrm{LO}$ and SAF, but the events of 1995 underscored the disadvantages of completely uncoordinated (industry-level) bargaining in a context in which unions are capable of backing up their demands with actions that export-dependent industries find extremely expensive in highly competitive and tightly integrated global markets. ${ }^{6}$

The lessons employers learned in 1995 set the stage for a reconfiguration of bargaining that is based on a strengthening of cooperation across industries and between labor and capital within the export sector, but largely at the expense of more encompassing forms of coordination and solidarity at the national level (see also Thelen 2001). In 1996, in a move spearheaded by the head of the metalworkers' union, Göran Johnsson, Metall joined with its white-collar counterpart (SIF) and other unions in export sectors; together they issued a public invitation to their counterparts on the employers' side to engage in joint negotiations over wage formation and mediation procedures to avoid costly conflicts of the sort they had fought the previous year (Dagens Nyheter, 1 June 1996, A4; see also Elvander n.d., 15). By March of 1997, eight unions and 12 employer associations covering the manufacturing sector as a whole had concluded a new "Agreement on Industrial Development and Wage Formation" designed to support "constructive negotiations" and to avoid "the need to resort to industrial action" (18 March 1997, appendix A, paragraph 1; see also Elvander n.d.). The agreement establishes an "Industry Committee" composed of equal numbers of representatives of unions and employers to oversee its implementation and-especially important-to select mediators ("impartial chairmen") who accompany and facilitate industry-level wage negotiations. The 1997 deal also contains a number of "practical rules" governing the bargaining process-for example, requiring unions to submit their demands well in advance of the expiration of current contracts, providing for the mediator to enter discussions well before the contract runs out, and allowing him/her to force a delay in planned industrial actions (Berg 2003a). In general the role of the mediators has served to promote peaceful compromise within industries, as well as to broker coordination across industries in the exposed sector as a whole (see also Elvander n.d., 22). 
For the unions, but especially for Metall, the agreement was important in prompting the VI to abandon its earlier efforts to push for full decentralization, thus ending years of struggle in this key industry over the structure of negotiations. ${ }^{7}$ Employers for their part have praised the new conflict mediation procedures that lie at the center of the agreement and that they see as crucial to managing their heightened vulnerability to interruptions in production, including strikes. As Nils Elvander has put it, the agreement "covers by and large the whole competitive sector in the Swedish economy, it bridges old class distinctions [between blue and white collar] on the trade union side, and it presents an entirely new model for collective bargaining and conflict resolution" (n.d., 15). The agreement thus puts to rest the wage competition between blocs (public versus private and blue versus white collar) that both unions and employers (particularly in engineering) had-for different reasons-come to find so problematic. It does so by delinking bargaining in the exposed sector from that in the sheltered sector, and by facilitating a closer interface between white- and blue-collar contracts in industry.

These new arrangements sideline the national trade union confederation LO rather completely, which is why that organization was unenthusiastic, if resigned, about the industry agreement. ${ }^{8}$ The LO has generally been casting about for a way to resuscitate some national-level forum in which it could continue to play a central role. One opportunity appeared to present itself in 1997 when the government (partly in response to developments in the export sector) formed a commission to explore the possibility of creating a new national mediation authority. ${ }^{9}$ Initially, the LO had favored the idea, hoping that such an institution would facilitate the linking of wage settlements across the economy and, with that, restore the LO to an important role in the bargaining process. However, representatives of the export sector (on both the labor and employer sides) opposed any government machinery that would circumvent or supersede the successful procedures they had worked out for themselves, a position that was respected in the legislation that ultimately emerged in 2000. Public-sector workers, for their part, were concerned with protecting their relatively newly won (1966) right to strike and hurried to conclude a voluntary agreement similar to the industry agreement in order to keep themselves out of government mediation machinery. ${ }^{10}$ As Anders Kjellberg $(2000,558-559)$ notes, the prospect of state regulation may have helped to spur greater attempts at self-regulation, and in fact by the end of 2001, 16 agreements covering over half of the entire workforce in Sweden had been concluded (Berg 2002b; Skiöld 2001).

These developments did not forestall legislation, however, and in 2000 a new national Mediation Authority (Medlingsinstitutet) was established, replacing the old, weaker National Conciliator's Office (Förlikningsmannaexpeditionen) (Skiöld 2001). The new authority was not intended to supersede, only to complement, the voluntary industry agreements; as one of the state officials who helped draft the bill remarked, the govern- 
ment much preferred the social partners to "solve their problems by themselves." 11 Thus, the new mediation authority specifically promotes and works around existing agreements and covers those industriestransportation and retail trade among them-that have no such voluntary agreement (Berg 1999; Skiöld 2001). Similar to provisions under the voluntary arrangements, the Mediation authority can encourage an early (prenegotiation) exchange of information between the bargaining parties and appoint a mediator to facilitate the negotiations themselves. The rules under the new law also call for advanced notice before anticipated industrial action by either party, and allow state mediators to force a postponement of such action (Berg 1999; Skiöld 2001). However, like the industry agreements, the mediators only have power of persuasion, and cannot impose a solution. In this sense the Swedish authority remains less powerful than its Danish counterpart even if many of the goals-to avoid industrial strife and especially to facilitate coordination across industries behind the lead of the exposed sectors-are the same. ${ }^{12}$ So far the new routines and procedures in Sweden appear to be quite successful in achieving these goals. Negotiations in a majority of industries in the 2001 and 2004 bargaining rounds were accompanied by mediators, and resulted in long-running (three-year) agreements (Berg 2002b, 2004). A partial exception came in 2003 when the municipal workers union (Kommunal) took advantage of a clause in the 2001 agreement to opt out of the existing (three-year) contract a year early, and struck for higher wages and a boost for lower-paid workers. The negotiations (again facilitated by a mediator) resulted in adjustments along these lines-but this was in large part a function of employers' own eagerness to increase the wages of low-paid healthcare workers to address intense labor shortages in that area (Berg 2003b). There were worries that this would lead to a cascading effect with unions in other industries demanding a similar deal. However, this was not the case and in fact most of the key industrial unions (including the metalworkers, the paper and pulp workers, and the Swedish Industry Workers union) were critical of the municipal workers union for its actions (Berg 2003b). The following year, 2004, industry again led the bargaining, and again signed a long-term contract. Other sectors were "more or less held back by the Mediation Authority (Medlingsinstitutet), which prefers the industry agreements to be settled first, thus maintaining the normal order in the labour market" (Berg 2004).

The negotiations surrounding the establishment of the Mediation Institute and subsequent developments reveal the constellation of interests and power relations behind the "new" Swedish model. There is high coordination within the exposed sector, where the resulting contracts also effectively set the pace for the country as a whole. However, any intimations of a resurrection of wage solidarism on an economy-wide basis have been vehemently rejected not just by SAF and the main employer associations for industry, but also by leading industrial unions such as Metall. Far from longing for the old system, Metall wants no part of any move- 
ment that would revive or reinstate the previous power of the peak union confederation, LO. All indications are that Metall is much more interested in cooperating with white-collar unions (and employers) within the metalworking sector than with coordinating with other blue-collar unions within the LO. ${ }^{13}$

These developments thus signal and institutionalize the end to solidaristic wage bargaining as it had come to be practiced in the 1960s and 1970s, and it comes as no surprise that they have been associated with increased wage dispersion (Hibbs and Locking 2000), as well as with heightened "tensions between unions representing low-paid groups and other unions whose members are in a better position" (Ahlberg 1997). Indeed, and as many commentators have noted, in the pattern bargaining system that has emerged under the industry agreement, local government and private-sector service workers have more or less been "left behind" (Ahlberg 1997; Berg 2002a) an outcome that is fully embraced not just by employers but also by unions in the key export sectors. In the 1998 collective bargaining round, for example, there was some informal coordination among blue-collar unions in the LO, but prominent unions in the export sector (above all metalworkers and paper workers) "threatened to back out if the low-paid were given 'too much' " (Ahlberg 1997). The criticisms leveled by these same unions against the actions of the municipal workers union in 2003 suggest that this has not changed much.

Summarizing developments from the early 1980s to the present, one could conclude that in the Swedish case, "employer coordination" has proved more resilient than adherents to a strict neoliberal offensive thesis might have predicted. Full decentralization to the plant level-as advocated in the 1980s and 1990s by prominent firms such as ABB, Volvo, and Ericsson-has been averted, and there is significant coordination across the industry sector as a whole. At the same time, however, the issue of "who is coordinating with whom" has shifted decisively-from coordination at a very encompassing, confederal level (but with white- and bluecollar workers negotiating separately), to coordination across the blue-/ white-collar divide and across export industries-but less closely linked to the public and private service sectors. In general, and as Kjellberg (2000) notes, since the 1990s, "union alliances based upon class were increasingly replaced by constellations based upon sector" (555).

The changes described above amount to a significant renegotiation of the terms of coordination, accomplished in two steps. In the first move, from confederal to industry-level bargaining, employers sloughed off several layers of coordination that they had come to view as a drag on their ability to restructure production and to maneuver effectively in increasingly competitive international markets. Above all, VI's initial withdrawal from peak negotiations dealt a double blow to solidaristic wage bargaining as traditionally practiced in Sweden (i.e., producing wage leveling both across industries and between skilled and unskilled 
workers within individual sectors). While some of the literature had treated this first move as an example of a neoliberal offensive by employers against labor, we have argued that it is actually more properly understood as the result of an intensification of cooperation between labor and capital in the metalworking industry at the expense of solidarity and coordination across sectors.

The second phase of reorganization/recoordination of bargaining across the industry sector (but separate from bargaining in the public and private service sectors) solidified and in some ways shored up this new arrangement. It solidified the arrangement by relinking the metal industry to other export industries, thus bringing potential rogues (like the paper and pulp industry was, in 1995) back into a form of coordination organized around what the industry sector as a whole can bear. It shores up this new arrangement, moreover, by acknowledging the negative effects (on both sides) of industrial conflict and by underwriting mutual restraint through the new mediation procedures.

We can say that Sweden is a coordinated market economy before and after. But this cannot obscure the fact that a significant shift has occurred. Above all, the $\mathrm{LO}$ has been decisively relegated to the distant sidelines when it comes to wage negotiations, and with that, wage solidarity on the old terms is irretrievably gone. Employers are, as one representative put it, "dead against" any return to national-level bargaining (under whatever auspices, either $\mathrm{LO}$ or under the auspices of the new national mediation institution) However, in their campaign against any such recentralizing initiatives they have been massively aided and abetted by the most powerful industrial unions (especially Metall), which have their own reasons to support the arrangements described above that rest on a new form of accommodation between labor and capital within key export industries.

\section{Germany}

German industrial relations were never centralized at the national level as in Sweden, but traditionally a high degree of coordination has nonetheless been achieved through multi-industrial bargaining under the informal leadership of the metalworking industry. It is precisely in this industry where the most important new "cracks" in the system have appeared. No one predicts a complete convergence of this relatively centralized model on, say, the U.S. system, but here, too, it seems clear that there are serious and undeniable pressures at work-and the outcome is in many ways still much more in flux at present than in Sweden.

The most sobering recent trends in Germany, by far, are the signs of organizational disarray in the Association of German Metalworking firms (Gesamtmetall) and its union counterpart (IG Metall), which together have played the key flagship role in Germany's de facto system of pattern 
bargaining over most of the postwar period. On the employer side, firms within the metal association have grown increasingly critical of "rigid" central contracts and have begun calling for reforms that would inject much greater flexibility to adapt central bargains to the needs of individual firms. More consequentially still, a significant number of firms have voted with their feet, withdrawing from the association and thus also from the terms of the central bargains it negotiates with the union. Such a trend is deeply destabilizing since, historically, rather high collective bargaining coverage rates in Germany (estimated for the 1960s at around $80 \%$ of all firms accounting for $90 \%$ of all workers-[Zagelmeyer 1997]) have always been a function of high employer organization, not union membership. Union organization in Germany is rather low, especially compared to Sweden, hovering around 30\% of all workers for most of the postwar period, as against Swedish unions' $80+\% .{ }^{14}$ However, employers have traditionally been extremely well organized, and this has stabilized encompassing bargaining because contracts signed by the employer associations cover all workers in the member firms, regardless of their status as union members or not (Thelen 1991).

The origins of contemporary tensions in the metalworking industry go back in part to a divergence in interests between different employers within Gesamtmetall itself. ${ }^{15}$ Simplifying somewhat, ${ }^{16}$ the system has traditionally rested on a particular kind of accommodation between the country's large export firms and its sizable sector of small and mediumsized firms (Mittelstand). The core of the deal was one in which large firms dominated the employer association (and its main decision-making bodies), but typically also bore the burden of industrial conflict in order to secure moderate settlements with the unions on a range of issues, including, but not limited, to wages. These settlements, it is important to note, did not exhaust the ability of these large firms to pay; there was room for them to "top up" the industry deal in subsequent plant-level bargaining with their own works councils, resulting in wages and benefits "above the going rate" (ïbertarifliche Leistungen). ${ }^{17}$ Such flexibility in the past was important in reducing pressure on centralized bargaining by providing an outlet for de facto (upward) differentiation based on conditions in individual firms (Thelen 1991).

Developments over the last 20 or so years have disrupted this basic deal, but as in Sweden the problem is not well captured by arguments that stress a straightforward neoliberal offensive waged by employers against labor. Some of the most destabilizing trends in fact go back to an intensification of cooperation between labor and capital at the plant level (especially in larger firms) - the "collateral" effects of which, however, have begun to interfere with continued coordination among firms and among workers at the industry level. Clear tensions began to emerge already in the 1980s, in the context of negotiations over working time reduction. A series of bargaining rounds in that decade produced reductions in regular working hours in several steps, down to 35 
hours throughout western Germany. Larger firms were able to offset the costs of such reductions by taking advantage of clauses allowing greater flexibility in working times-expanding shift work or devising differentiated working time arrangements. However, smaller companies were not able to make these same kinds of adjustments and thus were hit more heavily by the sheer costs of reduced working hours (Silvia 1997). ${ }^{18}$ Discontent within the employers association grew as smaller firms listed under the weight of agreements they felt did not reflect their interests.

The results of subsequent collective bargaining rounds in the 1990s did not ease and in many ways exacerbated problems of solidarity on the employer side. In key sectors such as automobiles, German producers had begun to face much stiffer competition from high-quality (lowercost) producers in Japan and elsewhere. These more competitive markets, along with more tightly linked production networks, increased dramatically the costs to firms of industrial conflict, because interruptions in production would result in lost market shares. Until the mid-1990s a typical ritual in German industrial relations was for a strike by the union (or threat thereof) to be met with a more or less equally effective lockout (or plausible threat of lockout) by the employers association. ${ }^{19}$ However, starting in 1995 (arguably much before, it only became manifest in the mid- to late 1990s), Gesamtmetall was unable to continue the previous pattern, as many of its members had become conflict averse in the extreme. ${ }^{20}$ Many of the core firms on which Gesamtmetall had traditionally relied to carry it through conflicts with the union could (as before) afford a somewhat higher wage settlement; they now much preferred this to the prospect of shouldering the burden of a conflict with the union that would bring losses in the market for which they could not possibly be compensated by the association and from which they could not easily recover.

The latter half of the 1990s thus witnessed a number of bargaining rounds that featured remarkable displays of disunity on the part of metalworking employers, and an utter incapacity to put together a credible lockout threat in the face of conflict with the union (on this, see especially Thelen and van Wijnbergen 2003). This situation led to a series of industry settlements that came much closer than ever before to exhausting the ability of the strongest firms to pay, in effect absorbing the flexibility mentioned above on which the internal political balance within the employers' association rested. On the basis of a survey of nearly eight thousand firms (in eastern and western Germany), Lutz Bellmann, Susanne Kohaut, and Claus Schnabel (1998) show that the percentage of firms paying wage increases over the collective bargain dropped from $60.6 \%$ in 1993 to $48.9 \%$ in 1997. Firms that did continue to pay above the going rate paid less, on average two percentage points less, than before (averaging across all firms) over those four years (Bellmann, Kohaut, and Schnabel 1998). What this means is that the weaker firms were being forced to pay 
wages much closer than before to those of the strongest companies (Hassel 1999; Hassel and Schulten 1998).

These developments in working-time regimes and in wages produced highly corrosive feedback effects, prompting a hemorrhaging of the employer association itself, as weaker firms began to opt out of the industry-level contract altogether. Sometimes these firms have severed ties completely; in other cases they have found their way into new organizations that have been constructed by, and alongside, the old employer associations and that promise all the previous benefits of membership, but do not commit the firms to the terms of the contracts negotiated with the unions (Verbände ohne Tarifbindung, or so-called OTVerbände). ${ }^{21}$ Either way, though, the result has been a growing number of firms outside the regular employers associations and, with that, also outside the system of industry-wide bargaining. Between 1990 and 2001, Gesamtmetall has recorded steady and very significant losses, as 30\% of its member firms in the West dropped out of the association in that period (Behrens 2002b). The trend in the East is even more dramatic, with $66.8 \%$ of firms there relinquishing their membership (Behrens $2002 b)$. Overall, larger firms are more likely to stay in the associations, so the number of workers affected is smaller than the number of firms. Nevertheless, collective bargaining coverage has eroded significantly. The most recent data available (for 2002, for the economy as a whole) reveal that the number of employees covered by industry wide agreements has fallen steadily in the West, from $72.2 \%$ in 1995 to $61 \%$ in 2002 . Figures for the East indicate a drop from 56.3\% in 1996 to only 35\% in 2002 (Behrens 2002a, 2004). ${ }^{22}$

In other words, intensified reliance of Germany's core firms on continued peace and stability in their relations with labor at the plant level has begun to feed back in deeply paradoxical ways, stabilizing the system in a formal sense (by deflecting demands for formal decentralization and allowing the union to reach settlements with employers in collective bargaining rounds), while at the same time undermining the deeper foundation on which the system rests (as central bargaining over time comes to cover a shrinking number of firms). Union victories over disorganized employers in key collective bargaining rounds in the mid- to late 1990s were therefore highly ambiguous. While some scholars have coded these events as system stabilizing (cases of successful union defense against employer attacks on the system), the results of these bargaining rounds generated instability by heightening Gesamtmetall's internal problems. Union leaders realize that their own ability to conclude binding and encompassing agreements hinges on continued organizational viability on the employer side, which is why their own celebrations of these victories were muted, and frequently accompanied by expressions of concern about the weakness of the employer association. ${ }^{23}$

Internal organization problems on the employer side complicate enormously the problems of coordination on the labor side as well. Different 
from Sweden, where large export firms such as $\mathrm{ABB}$ were among the most vocal proponents of radical decentralization, in Germany large firms are among the system's most loyal defenders. This is true because in fact (and often in contrast to smaller firms) large companies have been rather successful in negotiating the flexibility they need within the traditional framework (Hassel and Rehder 2001, 4). The local deals on working-time reduction with flexibility mentioned above are just one example of this. As Anke Hassel and Britta Rehder (2001) note, the 1990s have seen a growing number of company-level pacts for employment and competitiveness (betriebliche Bündnisse zur Beschäftigungs und Wettbewerbssicherung) in which managers are able to secure cost-saving concessions on working time and pay flexibility in exchange for increased job security. A survey of the 120 biggest companies in Germany indicates that in the 1990 s, $46 \%$ of these firms negotiated some kind of company-level pact along these lines, and a larger number have negotiated other kinds of arrangements (e.g., variable or performance-based pay) (Hassel and Rehder 2001). Such deals in some ways shore up the traditional system, providing as they do an outlet for demands for flexibility, therefore forestalling demands for more radical reform of the framework as a whole. But it is also clear that they intensify the problems that unions like the IG Metall face in forging solidarity among (and imposing uniform conditions for) workers across firms that are very differently positioned in the market.

Lack of unity and discord are therefore also prominent features of the IG Metall's internal politics at present. There have long been thinly veiled disputes within the union between so called "traditionalist" and "reformist" perspectives, with the latter generally seeking to shore up social partnership through targeted concessions to accommodate employers' demands for greater flexibility in bargaining arrangements. Such internal disputes explain the union's hesitant and sometimes erratic strategic course in recent years. Overtures and signals by the IG Metall of a willingness to accept some trade-off between wage restraint and employment have often been followed by determined calls for an end to moderation (Ende der Bescheidenheit). Some union leaders have been willing to agree to more moderate collective bargaining outcomes (e.g., greater differentiation in industry-wide deals along dimensions such as working times). However, such concessions are becoming harder to sell internally. Indeed, every movement in that direction exposes advocates to challenge from internal opponents who push for a more aggressive stand by the union (on the split in the union, see, e.g., Süddeutsche Zeitung June 13, 2003).

Such conflicts were vividly on display during and after an ill-conceived strike in the eastern metalworking industry in 2003. The specific demand on the table was a reduction in weekly working times in the East, from 38 to 35 hours, to match levels in the West. The demand was widely criticized by economists and had also in fact been rejected by union leaders in a number of regions the previous autumn (Spiegel, June 2, 2003, 
83). The head of the IG Metall, reformist Klaus Zwickel, had warned that a push for general working-time reduction in the East had no chance in the current economic and market environment (Spiegel, June 2, 2003, 83), but his vice president Jürgen Peters pushed forward and (narrowly) carried the day in the relevant decision-making bodies.

The strike failed, a first for the IG Metall since the 1950s. Early signs of trouble were reports of strike breakers and controversies about workers being brought in from the outside to man eastern strike posts. But the strike collapsed entirely in the face of opposition by powerful works councils in the West as soon as their own plants were drawn into the fray (Süddeutsche Zeitung, June 24, 2003, 20, June 25, 2003, 6). When parts shortages due to strikes in the East began to result in production stoppages elsewhere, many western works councilors and union officials complained that these indirect effects and the de facto expansion of the conflict was "never debated and never decided" (Süddeutsche Zeitung, June 21, 2003, 25). Internal conflict within the union, combined with growing unity and resolve among employers, forced union leaders to call off the strike, an unequivocal defeat for labor. ${ }^{24}$ The subsequent political fallout brought the union's divisions and conflicts painfully into the public spotlight, as competing factions blamed each other for the loss of the strike. Elections to choose a new union leader for the retiring Zwickel were pushed forward to try to resolve the crisis, but so deep was the schism and so evenly divided between the two sides that the union decided to allow the leaders of both factions to (try to) govern together (Süddeutsche Zeitung, July 1, 2003; Spiegel June 2, 2003, 72 76; Tagesspiegel, July 2003, 17; Frankfurter Allgemeine Zeitung, July 24, 2003).

To summarize, in Germany, as in Sweden, elements of stability and change are inextricably linked. Contrary to accounts that mostly emphasize conflicts between labor and capital, some of the most destabilizing trends go back to an intensification of cooperation between the two within particular kinds of firms (especially large firms), which complicates rather than reinforces coordination at higher levels. Aversion to conflict at the national level on the part of core firms in the West, combined with closer cooperation at the plant level between large firms and works councils in the interests of protecting employment has stabilized German industrial relations in a formal sense (avoiding a big fight over the system as a whole) while subtly undermining the foundations on which it rests (as coverage shrinks). Disarray and lack of unity on the employer side, so prominently on display in the late 1990s, have lately been overshadowed by an even more dramatic collapse of unity on the union side. But the problem in both cases is in part structural and has its roots in contemporary market and political developments as these have played into preexisting cleavages between firms and workers who are differently situated in the market and differently constrained and enabled by the current collective bargaining framework. 
Current instabilities, it must be emphasized, coexist alongside continued significant support among employers for maintaining the traditional system of coordinated industry-wide bargaining. Even in the midst of the 2003 conflict in the East, the head of Gesamtmetall, Martin Kannegiesser, worried about the IG Metall's internal divisions, emphasizing that Germany needs unions capable of enforcing their policies (durchsetzungsfähige Gewerkschaften). ${ }^{25}$ In a context where, like in Sweden, unions still command considerable power to disrupt production, and where, more in fact than in Sweden, social partnership has traditionally been characterized by periodic displays of force and mobilizations, employers such as Kannegiesser explicitly defend the collective bargaining system for the "order" and "predictability" that it helps to impose on the labor market (e.g., Die Zeit June 26, 2003, 18). German employers do not want to abolish the traditional framework so much as render it more flexible ${ }^{26}$ and indeed as we have seen, while they wait for reforms many firms are already helping themselves to existing possibilities to secure more flexibilityeither formally and within the parameters the system already allows (company-level pacts in many large firms, mostly negotiated with union participation) or outside the framework, through informal contraventions of the terms of the contracts. However, as Hassel and Rehder (2001, 1516) note, this trend has come bundled with an important reversal in the relationship between central agreements and plant bargaining. Whereas in the past plant-level bargaining implemented and often topped up industry agreements, the trend now is for collective bargains to implement and sanction practices that are in many cases already well advanced at the plant level. ${ }^{27}$

The corrosive effects of these developments are clear, but it is important to underscore that they are as much a product of new forms of cooperation between labor and capital within the system as they are a consequence of employer attacks on that system. For this very reason, the problem is knottier and more difficult to solve than a straightforward neoliberal offensive thesis might have it. What we see here is that employer coordination in Germany has traditionally rested on a particular balance of power within key employer associations and between these and unions. That being the case, the continued viability of these institutions is not really a question of labor's successful defense of the system (as many labor scholars argue), nor does it follow automatically from the efficiency effects of these institutions (as in the VOC perspective). Rather, continued stability relies on the reproduction (or perhaps renegotiation) of the political settlement on which these institutions rest. And against the sometimes optimistic leanings of much of the VOC literature, it seems there is no guarantee that German employers (or unions, for that matter) will succeed in reconsolidating their organizations on the basis of a new internal balance of power, despite the fact that their failure to do so might well be against their individual and collective interests. 


\section{Japan}

Many aspects of traditional Japanese industrial relations practices are also under undeniable tension and strain. Leftists criticize these challenges as a total attack on labor and assume that the breakdown of the existing system is inevitable because unions are too weak to resist. Proponents of neoliberalism and deregulation, by contrast, have celebrated initial steps to change industrial relations practices as the opening move in a broad, efficiency-enhancing, reform movement, while lamenting the slow speed of change. As in the other cases considered in this article, we can observe contradictory views on the robustness and trajectory of Japanese management practices, and as in Germany, the outcome seems to be uncertain at present.

Through the postwar period, Japanese industrial relations were characterized by a form of coordination that is different from Germany and Sweden in many important respects. The system in the past has rested on two pillars-"lifetime" employment practices and the seniority wage system-that predominated in the large-firm sector. Both practices date back to compromises in the economic turmoil after World War II, when management confronted militant demands by unions for job security and tenure-based wages. ${ }^{28}$ Over time management came to appreciate the merits of "lifetime" employment as a means to secure workers' loyalty to the company, and tenure-based wages also turned out to be economically rational so long as workers' skills continued to be upgraded over the course of their career in the firm. Indeed by the 1980s, many economists were pointing out how successfully this system operated in motivating workers to invest in their skills (e.g., Koike 1991, 1997).

Because these two pillars of traditional Japanese management practices operate at the level of the firm, industrial relations might appear not to rest on the kind of coordination among employers emphasized in the VOC literature. However, seniority wages and long-term employment practices are sustainable only if employers (at least large employers) coordinate among themselves. The seniority wage system, for example, is only viable where employers refrain from outbidding each other for entry-level workers. All firms, in other words, have to agree to hire entrylevel workers at relatively low wages and let their earnings rise over the course of their careers in the firm. This is linked to long-term employment as well, because it is ongoing skill acquisition that makes it sensible for a firm to maintain a "lifetime" commitment to workers-an alternative being to hire skills from the outside. ${ }^{29}$ In short, lifetime employment only works if workers start at low wages, and then gradually acquire skills that make them increasingly productive and valuable to the company. In that sense, both seniority wages and lifetime employment practices are founded on a degree of coordination, at least among core firms.

Whereas coordination in the German and Swedish systems takes place through highly formalized channels, in Japan it occurs somewhat less 
formally in the context of the Shunto wage bargaining system. ${ }^{30}$ Within the Shunto framework, intensive discussion and informal bargaining start well before the formal negotiations. Usually the national and industrylevel actors, such as Sohyo (General Council of Trade Unions) and Nikkeiren (Japan Federation of Employer Associations), discuss proposed wage increases for more than three months. This is a very political process, involving considerable tactical maneuvering, but it is also a process that allows the bargaining parties to share information. Since the 1960s, the metal industry had become the main pattern-setting industry. Bargainers in this export-oriented sector care about its competitiveness, and unions, organized in the IMF-JC (International Metal Workers' Federation Japan Council), have traditionally demanded "economically rational" wage increases. The wage levels thus established then set the pace for other industries. Employers benefited from this Shunto coordination as a way to control competition (Sako and Sato 1997; Sato 2001, 255), allowing them as noted above to maintain the seniority wage system as well as the "lifetime" employment practices as effective incentive mechanisms for workers.

As in the other two country cases considered above, recent developments have introduced new strains into these traditional practices and institutions. The long economic downturn since the bursting of the bubble economy has robbed management of confidence in long-term employment, especially as business leaders and economists began to argue that the practice had to be abandoned to revitalize Japanese industry. When the financial-sector crisis deepened in 1998, more companies began discussing "restructuring," by which they in fact meant layoffs. According to the survey of labor economy (Rodokeizai Doko Chosa), in the early 1990s, employment adjustments had mainly been accomplished by reducing overtime work and by reassigning jobs within the same firm or across firms in the same keiretsu group. By the late 1990s, the percentage of early retirements-the main mechanism in Japan for actually reducing the workforce-had increased (Ministry of Health, Labor, and Welfare, all years).

Recent years have also seen intensified questioning of the traditional wage system. Employer organizations such as Keidanren (Federation of Economic Organizations) and Nikkeiren ${ }^{31}$ have criticized seniority wages as rigid and debilitating for Japanese firms. Advocates of change usually cite three developments that make this wage system increasingly untenable (e.g., Miyamoto 1997). The first is that demographic change (an aging workforce) has increased the number of older workers, and with that, increased also the total wage costs that firms must bear. A second reason is the alleged change in the nature of the seniority wage system, which has come closer to an automatic wage raise for many workers despite different job capabilities among workers of the same age (i.e., a loosening of the link between wages and productivity-enhancing increases in skills). ${ }^{32}$ Third, in some industries, especially electrical equipment, new technology (the "IT revolution") has changed the kinds of skills that firms 
need, such that traditional on-the-job training over a worker's career is less attractive than hiring engineers with the relevant skills from outside the company (Miyamoto 1997). For these reasons, many companies have moved to abolish the seniority wage system, often replacing this with performance-based wages. In some cases this translates into a straightforward job-based wage system, but another variation is management by objective (MBO), in which individual workers are assigned specific goals once a year and paid a wage based on the extent to which the assigned target is met.

However, as in Germany and Sweden, one finds in Japan evidence of continued employer support for both lifetime employment practices and substantial aspects of traditional wage systems. In 1995, Nikkeiren published a report, "A Japanese Management System in the New Era," advocating that firms distinguish among three different types of workers: longterm employed workers with accumulated skills, workers with professional skills, and short-term/flexibly employed workers. While this report is often read as evidence that Nikkeiren abandoned its commitment to Japanese employment practices (the second two types of workers), it is also noteworthy that Nikkeiren sees the first type of worker still as the core of the labor force and essential to Japanese enterprises. In general, Nikkeiren has been very vocal in defending employment security. In 1999, Chairman Hiroshi Okuda, in a seminar for top managers, argued, "Even if there are redundant workers, it is management's responsibility to seek new business opportunities to redeploy them. Employers without the entrepreneurship to find such business opportunities should retire." ${ }^{\prime 33}$ The chairman of the board of Fujitsu concurred with Okuda in this seminar, citing his company's successful efforts to retain (through retraining and redeployment) 500 workers made redundant in a recent restructuring (Nikkei August 6, 1999). One informed labor specialist who has been influential in making employment policy in the Ministry of Labor (now the Ministry of Health, Labor, and Welfare) recalled that this Nikkeiren seminar was a watershed in the discourse on labor mobility. ${ }^{34}$ According to this specialist, employers who had been thinking about radical reduction of employment became very hesitant after this speech. ${ }^{35}$ In sum, Japanese employers are not sure to what extent long-term secure employment should be reformed or how to accomplish it. Here we can see the efficiency of the traditional management practice producing resiliency, as the VOC thesis predicts.

The same observation can be made for the reform of the wage system. It is true that more companies have actually implemented reforms of the wage system than of "lifetime" employment. However, they have embraced it much more gingerly than many popular accounts suggest, realizing how difficult it is to maintain high commitment and morale among workers with the new performance-based system. One company that pioneered such reform, Takeda Chemical (the largest pharmaceutical company in Japan), found it difficult to keep employees committed to the 
company. Managers had expected that the new wage system would be very popular among workers, but when union surveys revealed only very ambiguous (and in fact declining) support for the reforms, the company began fine-tuning the system to shore up worker loyalty to the company (Yanagishita 2003). Fujitsu, another pioneer of wage reform in the 1990s, introduced a performance-based annual salary system for managers in 1993, and then expanded it to all employees, abolishing the seniority element in the wage portfolio. However, company management subsequently realized that workers became too concerned with short-term goals, to the detriment of the company's ability to develop competitive products. Thus, in 1999, Fujitsu decided to incorporate the company's performance as a whole as well as the individual worker's performance, into the salary calculation (Nikkei February 5, 2000). In these processes of experimentation, Fujitsu management came to the conclusion that it is important to evaluate workers' potential ability and "work process" independently of "outcome" (Asahi March 19, 2001; Joe 2004; see also Takewaki and Suyama 2002, 77-79).

The major problem with which managers have been grappling is how to make individualistic wages compatible with the group-oriented work organization characteristic of Japanese firms. Many companies are eager to preserve essential features of traditional practices even as they finetune their reformed wage systems in order to maintain their institutional competitiveness (Takahashi 2004). Nippon Steel Corporation decided to introduce a new performance-based wage system for its Electronics and Information Division. However, managers worried that a fully individualized wage system would create "winner take all" situations that would weaken work organization, and decided instead to take the performance of the division as a team into account in wage calculations. Similar adjustments are often made in other companies that are trying to reform the seniority wage system (Nikkei February 5, 2000). Some companies (e.g., Seiko) realize that in order to develop workers' skill, a simple "outcome"based evaluation would not work effectively (Nikkei Sangyo November $27,2000)$. It is also telling that while Toyota is willing to reform its wage system toward greater performance orientation, it continues to emphasize job capability and group performance in wage determination.

Moreover, like a significant number of other companies, Toyota seems convinced that secure employment should be the basis of its competitiveness. ${ }^{36}$ When Moody's Investors Service downgraded Toyota's long-term debt from Aaa to Aa1 (claiming that its commitment to "lifetime" employment would hamper its competitiveness), Toyota management counterargued that such an employment practice should be a source of strength (Nikkei Sangyo, October 1, 1998). ${ }^{37}$ Nissan is another instructive case. It was taken over by the French automaker Renault in 1998 due to its financial difficulties and went through a very tough restructuring with massive dismissals (in the form of voluntary retirements). However, after achieving a V-curve recovery, President Carlos Ghosn maintained a 
bottom-up decision-making style, which is regarded as very Japanese (Ghosn 2001), and made it clear that the company's main strength should reside in worker commitment to the firm. In wage bargaining for 2001, and in the context of concerns about revitalizing work organization, Nissan unilaterally declared that it would pay the full amount of bonuses demanded by the union. Even the information technology company Fujitsu, which was the vanguard of wage-system reform in the 1990s, is willing to maintain secure employment as a basis of its competitiveness.

However, not all companies can accomplish this same balance-incorporating elements of traditional employment practices while fine-tuning their reformed wage systems. An emerging important new divide among core firms in the Japanese economy is between stronger firms (such as Toyota) which have been careful to preserve some of the essential strengths of the traditional system by intensifying their relationship with core workers (even as they may adopt more flexible wage systems), and weaker firms which have moved away from traditional practices (including laying off workers) in a straightforward effort to reduce labor costs. For example, Mazda abandoned seniority-based wages in favor of a more performance-based system in part because the company could no longer afford Toyota-style wage and employment practices (Sako 2001). ${ }^{38}$ In cases like Mazda, radical reform of the wage system often wound up demoralizing workers, and did not improve company competitiveness (Yanagishita 2003). ${ }^{39}$

This emerging divide now seems to be jeopardizing employer coordination in Japan. In the 1990s, as stronger and more profitable companies began introducing performance-based wage systems that also took company performance into account, wage increases across firms within the same industry became more diversified. This trend was strengthened by the fact that individual companies were more willing to compensate workers with bonuses rather than salary increases, in order to maintain flexibility in managing total labor costs. ${ }^{40}$ Here it becomes clear that the increasing adoption of performance-based wage systems has made it very difficult to maintain the traditional Shunto system. As practiced in the past, Shunto coordination required leading firms to act as pattern setters both within their own industry and also with an eye to other industries for which their settlement would provide the benchmark. Performancebased wages interfere with this because it is more difficult to coordinate wage increases once company profits begin to play a prominent role in wage determination (not to mention individual performance targets). This had become a problem already in the 1990s when Takeda Chemical Industry and Mitsui Mining and Smelting adopted performance-based wages and simply left the Shunto framework altogether.

In this context, Toyota's behavior in the 1997 Shunto wage round is very revealing. Early on in the negotiations, Toyota management argued that wage increases should be moderated in order to change the "highcost economy." At the time, many employers had been arguing that inter- 
nationally high labor costs had made it unattractive for them to do business in Japan, and were especially critical of the high wages in protected sectors such as services and energy. Toyota management worried that if Toyota, which was actually booming thanks to the weak yen, raised the regular wage, this result would spill over into other industries and exacerbate the high cost problem. As an alternative managers proposed that the increased company profit be distributed in the form of bonus payments, which are less linked to the Shunto (Nikkei March 20,1997).

In the end, however, Toyota decided to increase its regular wage by a larger margin than other companies in the metal sector did, in effect abdicating its role as benchmark and pattern setter. ${ }^{41}$ This was a surprise attack on many companies. The president of Nissho (Japan Chamber of Commerce and Industry) criticized Toyota for its unilateral decision. Other auto companies had to catch up with Toyota by adding extra raises (Nikkei Sangyo March 24, 1997). Faced with criticism, Toyota's president, Hiroshi Okuda, bluntly said that Toyota should not care about other companies or industries and should choose the best course for itself. He believed that in the days of globalized competition, survival of the fittest was the rule, and argued that for Toyota it was very important to motivate workers in order to make its work organization more competitive (Nikkei March 20, 1997).

While other strong firms have attempted to match Toyota wages, ${ }^{42}$ the more interesting impact is on weaker firms. In the traditional Shunto negotiations, more profitable companies specifically took the situation of weaker firms into account in setting wage levels, which allowed the latter to keep pace. But in uncoordinated competition, this becomes very difficult. As suggested above, uncoordinated competition in fact often drives weaker companies to introduce more individualistic performance wages in a straightforward attempt to reduce labor costs-and therefore not necessarily combined with measures to preserve traditional strengths of traditional management practices such as a continued commitment to secure, long-term employment. These trends increase the divide between stronger and weaker firms, but they also may feed back in ways that over time create new problems for the stronger firms. Recently, fewer and fewer young Japanese workers take seriously the promise and prospect of secure long-term employment. ${ }^{43}$ This trend has been exacerbated by the introduction of individualized performancebased wage systems and the loosening of a commitment by employers to long-term employment. To the extent that the expectations and therefore strategies of workers shift, Toyota and other stronger companies may not be able to motivate workers with the promise of secure employment in the future.

The effects of these trends on union coordination are also important in Japan. As discussed above, wage coordination through Shunto has been very useful for employers. But it should be remembered that Shunto was invented as a union tactic, and as in the other cases, new strains on the 
union side are also contributing to the destabilization of Shunto coordination. For example, the Steel Workers Federation adopted an alternateyear wage negotiation in 1997, which in effect delinks wage bargaining in this sector from other industries. In addition, the Electrical, Electric, and Information Union (JEIU) endorsed performance-based wages in 1997, weakening the coordinating function of Shunto in a different way (Weathers 2003). One official of the JEIU in the 1996 Shunto commented, "We couldn't stand our wage raises being used by unions in other industries as springboards to get raises higher than ours" (cited in Weathers 1999, originally Asahi March 9, 1996). It seems that unions in exportoriented sectors, which used to be central players in Shunto, are now playing a role in its dissolution. Moreover, and as emphasized above, in strong companies such as Toyota, workers enjoy better benefits, including higher raises, than in other companies and industries. Therefore, as in the other cases considered in this article, we can find a kind of labor-management cooperation in the core sector behind changing Japanese management practices.

To summarize, we may be able to say that, like in Germany and Sweden, instabilities in the traditional system are not produced by a neoliberal offensive against labor. Rather, they are generated by the policies of large, successful firms to pay workers well and to guarantee their employment. In the Japanese case these efforts have created pressures that weaker firms can often only address by retreating from traditional practices.

\section{Conclusion}

In the cases of Sweden, Germany, and Japan, market dynamics since the 1980s and especially the 1990s have introduced new strains into previously stable institutions of employer coordination. The new tensions are both more interesting and more intractable for defenders of the systems to address than a straightforward neoliberal offensive in which we would be seeing employers pressing for decentralization and deregulation and unions seeking to defend the system. Instead, in all three cases, we find that recent market developments have brought an intensification of cooperation between labor and management in some companies and industries that has complicated traditional forms of coordination (at higher levels) among employers and solidarity among workers on which these systems previously rested.

In the case of Sweden, the crucial break with peak-level bargaining reflected an intensification of cooperation between labor and capital in the metalworking industry in the face of shared market pressures. It was followed by a reconfiguration of bargaining that suited the needs of the resulting new power constellation-based on greater coordination across the industrial sector (and within industries between blue- and whitecollar unions) - but at the direct expense of traditional forms of coordina- 
tion premised on solidarities between public and private sector and lowand high-skilled workers. In Germany, intensified cooperation between labor and capital in large firms-mostly revolving around efforts to stabilize employment-has had deeply destabilizing collateral effects and operated in ways that complicate rather than consolidate continued coordination across different kinds of firms at the industry level. The Japanese case, finally, is also one in which current strains run through industries and across companies-as stronger firms combine traditional practices with new worker-incentive schemes in ways that make it difficult for weaker firms to sustain even those aspects of the traditional system they would prefer not to abandon.

The point of this article has been to explore the effects of recent developments on employer coordination in Sweden, Germany, and Japan. In each case we find that the varieties of capitalism literature are quite right to point out that contemporary market developments have in some ways intensified the interests of employers in particular kinds of (traditional) industrial relations institutions. Where this literature often falls short, however, is in viewing employers within a given national context as essentially homogenous in their interests and, as a consequence, in seeing all signs of intensified commitment to traditional institutions by firms as operating to stabilize these institutions. What we have shown, by contrast, is that the intensification of cooperation within traditional institutions in some industries and companies has in fact made it difficult for others to keep pace, and so we see a destabilization of the system that is brought about by precisely those forces that the VOC literature sees as sustaining the system.

While Sweden may have found a new equilibrium or at least a stable resting point for coordination for the time being (which is still very different from that in the liberal market economies), Germany and Japan appear to be still in a rather fluid state of renegotiation and flux. One reason for the divergence on this score may well be the role that the Swedish state played in stimulating and facilitating employer (re-)coordination. While Swedish industrial relations are governed by the principle of collective-bargaining autonomy and low state intervention (as they are de jure in Germany and de facto in Japan), the threat of a new and potentially quite powerful state mediation authority galvanized support for voluntary arrangements designed to facilitate the revival of employer coordination on new terms. ${ }^{44}$ In Germany and Japan, the state has so far been unwilling and/or unable to help unions and employers find a way out of the current, severe, collective action problems they confront. Despite such differences, however, a common trend across all three cases is toward new or more virulent forms of dualism-featuring firms or sectors characterized by intensified cooperation between management and labor, but facilitated and perhaps even underwritten by a growing gap between practices and outcomes within the new core and those outside it. 


\section{Notes}

1. For helpful comments on earlier versions of this article, we thank Peter Hall, Charlie Jeffery, Bo Rothstein, Christa van Wijnbergen, and Nicholos Ziegler.

2. For a more elaborated version of these arguments see Thelen $(2000,2001)$.

3. In Hall and Soskice's (2001) treatment, coordinated market economies include Norway, Sweden, Japan, Germany, Switzerland, and Austria, while liberal market economies comprise the Anglo-Saxon countries-Britain, United States, Ireland, Canada, and Australia.

4. These arguments are laid out in detail in Thelen $(2000,2001)$.

5. In three negotiating rounds subsequent to this, peak negotiations did take place. However, in each case these came about as a result of either direct government intervention or special circumstances (as in 1986, in the aftermath of Olof Palme's assassination). Since 1993, there has never been peak bargaining along the old lines.

6. Increasing central bank autonomy also played a role in motivating employers to coordinate bargaining across the exposed sector. The Swedish Central Bank had been gaining independence since the 1980s, a trend that was subsequently (1998) written into the constitution. We thank Bo Rothstein for emphasizing this to us.

7. Indeed, Verstadsindustrier (VI) was the last to sign on to the deal in 1997, and some prominent firms in the association only reluctantly abandoned their demands for a more radical solution.

8. Neither the Landsorganisationen (LO) nor the peak-level white-collar bargaining cartel that once negotiated for white-collar workers has any role at all in wage bargaining any more (Kjellberg 2000, 555-556).

9. The commission was headed by Svante Öberg, former head of the Central Bureau of Statistics. Öberg clearly saw the 1997 industry agreement as a step in the right direction, but his proposals (not all of them adopted in the end) went further in stressing the link between wage formation and overall macroeconomic conditions and in imposing even stronger restrictions on industrial conflict (interview with Öberg in Stockholm, 1999).

10. Interview with representative of Kommunal, Stockholm 2000; also Skiöld (2001) and Berg (2002b).

11. Interview with Anna Ekström, in 2000, state secretary of Ministry of Industry, Employment and Communications.

12. In Denmark, the tradition of stronger mediation and a stronger role for the state more generally goes back to the 1930s. While Denmark, like other countries, has seen a decentralization of bargaining over the last decades, in that country continued high coordination across industries has been accomplished through a more powerful state mediation authority, but with strong supporting roles played by the peak trade union and employer confederations (see, e.g., Jorgensen 2004).

13. Interview with representative of Metall, 2000, Stockholm; see also Kjellberg (2000).

14. Unionization rates in Germany are also declining, not only in metalworking but across the board (Behrens 2003).

15. For a full analysis of current strains in Germany, see Thelen and Kume (1999) and Thelen and van Wijnbergen (2003) on which we draw here.

16. The shorthand distinction between small and large firms employed here is a simplification of a more complex set of divisions whose roots go back more to production strategies that are often related to, but not really reducible to, size differences (Thelen and van Wijnbergen 2003).

17. Works councils in Germany are formally independent from unions, and by law they cannot interfere with union wage setting. Thus the additional 
benefits achieved were not "secured" through the central contract (nor could they be defended with a strike).

18. Research by Hermann et al. (cited in Hassel and Rehder 2001) notes that a majority of small firms stuck with a standard work week while over $80 \%$ of large companies abandoned this in favor of more flexible working times.

19. This was typical for the pattern-setting metalworking industry, but not true for other industries such as chemicals where social partnership since the 1970s has not relied on these periodic shows of force.

20. A change emphasized to me, especially by Dieter Kirchner, former head of the Metal Employers Association, Gesamtmetall (interview, 1999).

21. These OT-Verbände are founded by the employers associations themselves, and they are often housed in the same building and staffed with the same personnel. Partly this has been a rearguard action on the part of employer associations who otherwise would have lost all contact with these firms (interview with representative of metalworking employers for BerlinBrandenburg). Partly it has evolved into an offensive strategy-a tool for putting pressure on the union to make-flexible contracts against the alternative of having to fight for separate contracts in each of the breakaway firms. Either way, the incentives are somewhat perverse because the creation of organizations with most of the benefits of traditional membership and minus the rigidities of the industry contract arguably hastens the exodus out of the employer associations that the OT-Verbände were in part meant to shore up.

22. This is not to mention the $22 \%$ of German establishments that make use of so-called opening clauses in centrally negotiated contracts that specifically allow deviation from industry norms, nor the reported $15 \%$ of companies that simply contravene contracts informally in one way or another (figures from 1999/2000) (Schulten 2001). The number of company-level agreements has also grown steadily, from 2,550 in 1990 to 6,415 in December of 2000 (Behrens 2002a).

23. See, for example, Frankfurter Allgemeine Zeitung (April 6, 1995); also Handelsblatt (March 24, 1999); and Offenbach Post (December 10, 1996), which quotes a representative of the union as saying, "Chaos reigns at Gesamtmetall; it is a catastrophe."

24. One union functionary criticized the strike as "the biggest auto-goal the union has ever shot" (Süddeutsche Zeitung June 24, 2003, 1). Even in the midst of the conflict, the BMW works council was already thinking about ways to use flexible work times to make up for time and production lost during the conflict (Süddeutsche Zeitung June 25, 2003, 6).

25. Asked after the union's defeat whether he was happy to have "broken the back of the union," Kannegiesser replied that he considered "such statements nonsense. It is not our goal to break the union, but rather to achieve reasonable results. Unfortunately this was not possible in this case" (Süddeutsche Zeitung June 30, 2003, 2).

26. A survey from 2003-2004 of 500 managing directors in the metalworking industry shows that a majority "do not want to abolish industry-wide collective agreements, but they do want to create a great deal more flexibility within these agreements." Employers complain about the German system, but as the managing director of Gesamtmetall, Werner Busch, put it, "According to our members, the collective agreement is considerably better than its reputation" (Funk 2004).

27. The 2004 agreement in metalworking is a case in point. This contract contains a clause allowing for plant bargaining to increase working-time flexibility by allowing for an extension of individual weekly working hours to 40 without overtime pay. Because workers in many companies routinely 
worked more than the standard 35 hours anyway, the main effect is to reduce labor costs by eliminating the overtime bonus for these extra hours (Dribbusch 2004). Companies like Siemens and Daimler Chrysler seized the new opportunity to conclude plant-level deals to that effect (Die Zeit July 1, 2004, 19; Spiegel July 19, 2004), and many more such agreements are in the works.

28. For a full analysis, see Kume (1998).

29. Some scholars emphasize that a shared belief in lifetime employment plays a very important role in sustaining this system. See Chuma (1994); Milgrom and Roberts (1992); Sai (2002).

30. It must not be forgotten that although the Shunto framework is functional in many respects for employers, it actually began as a union tactic to raise wages.

31. These two employer associations merged into one big employer organization, Nippon Keidanren (Japan Business Federation) in May 2002.

32. The seniority wage system was originally a compromise between management, who wanted to make it more merit based, and unions, which wanted to keep it need based. Many companies have their own pay tables, consisting of detailed job capability classifications and ranks within each classification. The basic idea is that if a worker acquires skill, he or she can climb up the ladder and receive pay raises. Unions expected that most workers would climb this ladder according to seniority, while management hoped it could be selective in classifying individual workers and thus could motivate them effectively. In the 1980s, management tended to be less selective but gave automatic raises.

33. Nikkeiren chairman Hiroshi Okuda advocates "capitalism with a human face." Although he is known as a committed reformer as a chairman of the board of Toyota Motors, he does not believe in liberal, Anglo-Saxon-type capitalism. This Nikkeiren stance is sometimes contrasted with Keidanren, which is believed to be one of the main forces pushing the Japanese economy in a liberal direction. After their 2002 merger, some worried that Keidanren's preference would prevail over Nikkeiren's, but it was decided that Chairman Okuda would be the first president. This means Nikkeiren preferences may prevail in the new organization, Nippon Keidanren.

34. This comment was made in a workshop on Legal Regulation of Employment sponsored by the Ministry of International Trade and Industry, June 6, 2001, Tokyo.

35. The preferences and behavior of young workers also plays a role. For instance, Matsushita Electric Industry Company introduced a new pay schedule not premised on long-term employment and was shocked when many young workers opted against it. Furthermore, many employers worry that better workers who can find better jobs outside tend to leave their companies, damaging the companies' competitiveness through weakened worker commitment to the company, reduced cooperation within the work organization, and less investment in skill formation.

36. Labor economists found that companies that invest in research and development tend to employ more regular full-time workers with secure employment (Higuchi 2001, 341). Without secure employment, workers would not acquire the necessary skills for a given company, which would reduce the company's technological advantage (Chuma 1994, 1998).

37. Moody's upgraded Toyota's long-term debt to Aaa in August 2003 (Nikkei August 1, 2003).

38. Ford Motor's takeover of Mazda clearly also played a role, but Toyota's sales per employee were twice as large as that of Mazda (Nikkei Sangyo March 24, 1997). 
39. The radical reform improved Mazda's financial situation in the short run, but fell short of revitalizing the company.

40. It is easier to reduce bonuses than salaries. Furthermore, because the size of the bonuses became a topic of the Shunto wage negotiation in the 1990s, it has become more difficult to find a standardized wage level.

41. Toyota was believed to play the role of pattern setter, taking the national economy into account because its former president was then president of Keidanren, the most prestigious national employer association.

42. Honda, for example, which had increased its market share dramatically, tried to pay wages closer to those paid by Toyota, although its labor costs are much higher than Toyota's. Nissan tried to pay large bonuses to motivate its workers against Toyota in 2001. This competition may create some problems in controlling labor costs even for Toyota in the future.

43. Even in very "Japanese" companies such as Matsushita Electric Industrial Company, the majority of newly recruited fresh graduates are not sure they will continue to work until retirement age. The more companies abandon an employment commitment, the more young workers, who are expected to be the core workforce, will lose confidence in the Japanese employment system. This concern seems to be why Hiroshi Okuda, former president of Toyota and now president of Nikkeiren, declared that companies are responsible for secure employment.

44. Much as the original Saltsjöbaden Agreement between Swedish unions and employers (in 1938) had occurred against the threat of legislation.

\section{References}

Ahlberg, Kerstin. 1997. "Blue-Collar Unions Concentrate on Low-Paid Workers." EIROnline [cited October 1997]. See <www.eiro.eurfound.eu./int/1997/10/ feature/se9710145f.html>.

Behrens, Martin. 2002a. "Collective Bargaining Coverage Continues to Decline." EIROnline. See <http://www.eiro.eurofound.eu.int/2002/01/feature/ de210199f.html>.

2002b. "New Study Analyses Development of Employers' Associations." EIROnline [cited 2004]. See <http://www.eiro.eurofound.eu.int/2002/12/ feature/de021220f.html>.

— 2003. “Union Membership Continues to Fall." EIROnline. See <http:// www.eiro.eurofound.eu.int/2003/02/inbrief/de0302201n.html>.

- 2004. "Coverage of Collective Agreements and Works Councils Assessed." EIROnline. See <http://www.eiro.eurofound.eu.int/2004/01/feature/ de0401106f.html>.

Bellmann, Lutz, Susanne Kohaut, and Claus Schnabel. 1998. "Ausmaß und Entwicklung der übertariflichen Entlohnung [Extent and Evolution of Pay 'Above the Going Rate']." IW-trends 2.

Berg, Annika. 1999. "New Mediation Authority to Be Established." EIROnline [cited 2004]. See <www.eiro.eurofound.eu.int/1999/12/feature/se9912110f. html>.

_ 2002a. "Blue-Collar Workers' Pay Falls Behind." EIROnline [cited December 2002]. See <www.eiro.eurofound.eu.int/2002/12/feature/se0212104f. html>.

- 2002b. "Collaboration Agreements and Statutory Mediation Helpful in 2001 Bargaining Round." EIROnline [cited March 2002]. See <www.eiro. eurofound.eu.int/2002/03/feature/se0203105f.html>.

_. 2003a. "Industrial Conflict at Low Levels." EIROnline [cited December 2003]. See <http://www.eiro.eurofound.eu.int/about/2003/02/feature/ se0302102f.html>. 
2003b. "Two-Year Pay Agreement Reached for Municipal Workers after Strike." EIROnline [cited June 2003]. See <www.eiro.eurofound.eu.int/2003/ 06/feature/se0306103f.html>.

- 2004. "First Agreements in 2004 Bargaining Round Concluded in Industry." EIROnline [cited March 2004]. See <www.eiro.eurofound.eu.int/2004/ 03/feature/se0403103f.html>.

Berger, Suzanne, and Ronald Dore, eds. 1996. National Diversity and Global Capitalism. Ithaca, NY: Cornell University Press.

Boyer, Robert, and J. Rogers Hollingsworth, eds. 1997. Contemporary Capitalism: The Embeddedness of Institutions. New York: Cambridge University Press.

Chuma, Hiroyuki. 1994. Nihongata koyo shisutemu no anteisei [Stability of Japanese Employment System]. Business Review 41:51-68.

- 1998. Kaikoken ranyo no hori no keizaibunseki [Legal Principles of Abusing the Right to Fire]. In Kaishaho no keizaigaku [Economics of Firm], ed. Yoshihiro Miwa, Hideki Kanda, and Noriyuki Yanagawa. Tokyo: Tokyo University Press.

Dribbusch, Heiner. 2004. "New Collective Agreements Signed in Metalworking." EIROnline. See <http://www.eiro.eurofound.eu.int/2004/03/feature/ de0403203f.html>.

Ebbinghaus, Bernhard, and Philip Manow, eds. 2001. Comparing Welfare Capitalism: Social Policy and Political Economy in Europe, Japan and the USA. London: Routledge.

Elvander, Nils. 1997. The Swedish Bargaining System in the Melting Pot. In The Swedish Bargaining System in the Melting Pot: Institutions, Norms, and Outcomes in the 1990s, ed. Nils Elvander and Bertil Holmlund. Solna, Sweden: Arbetslivsinstitutet.

- n.d. The Industrial Agreement: An Analysis of Its Ideas and Performance. Stockholm ALMEGAs förlag.

Ferner, Anthony, and Richard Hyman, eds. 1998. Changing Industrial Relations in Europe. Malden, MA: Blackwell.

Funk, Lothar. 2004. "IW Conference Examines Current Trends in Collective Bargaining." EIROnline. See. <http:/ / www.eiro.eurofound.eu.int/2004/03/ feature/de0403104f.html>.

Ghosn, Carlos. 2001. Renaissance. Tokyo: Diamond-sha.

Hall, Peter A., and David Soskice, eds. 2001. Varieties of Capitalism: The Institutional Foundations of Comparative Advantage. New York: Oxford University Press.

Hassel, Anke. 1999. "The Erosion of the German System of Industrial Relations." British Journal of Industrial Relations 37:484-505.

Hassel, Anke, and Britta Rehder. 2001. "Institutional Change in the German Wage Bargaining System: The Role of Big Companies." MPIfG Working Paper 01/9. Cologne.

Hassel, Anke, and Thorsten Schulten. 1998. "Globalization and the Future of Central Collective Bargaining: The Example of the German Metal Industry." Economy and Society 27:541-577.

Hibbs, Douglas A., Jr., and Hakan Locking. 2000. "Wage Dispersion and Productive Efficiency: Evidence for Sweden." Journal of Labor Economics 18:755-782.

Higuchi, Yoshio. 2001. Koyo to shitugyo no keizaigaku [Economics of Employment and Unemployment]. Tokyo: Nihonkeizaishinbunsha.

Iversen, Torben. 1996. "Power, Flexibility and the Breakdown of Centralized Wage Bargaining: The Cases of Denmark and Sweden in Comparative Perspective." Comparative Politics 28:399-436.

Iversen, Torben, Jonas Pontusson, and David Soskice, eds. 2000. Unions, Employers, and Central Banks: Macroeconomic Coordination and Institutional Change in Social Market Economies. New York: Cambridge University Press.

Joe, Shigeyuki. 2004. Uchigawa kara mita Fijitsu [Fujitsu from Inside]. Tokyo: Kobunsha. 
Jorgensen, Carsten. 2004. "Private Sector Settlement Approved in Ballot." EIROnline [cited May 2004]. See <www.eiro.eurofound.eu.int/2004/05/feature/ dk0405102f.html>.

Kapstein, Ethan. 1996. "Workers and the World Economy." Foreign Affairs 75:1637.

Katz, Harry. 1993. "The Decentralization of Collective Bargaining: A Literature Review and Comparative Analysis." Industrial and Labor Relations Review 47:322.

Katz, Harry, and Owen Darbishire. 1999. Converging Divergences. Ithaca, NY: Cornell University Press.

Kitschelt, Herbert, Peter Lange, Gary Marks, and John D. Stephens, eds. 1999. Continuity and Change in Contemporary Capitalism. New York: Cambridge University Press.

Kjellberg, Anders. 1998. "Sweden: Restoring the Model?" In Changing Industrial Relations in Europe, ed. Anthony Ferner and Richard Hyman. Oxford: Blackwell, 57-117.

- 2000. "The Multitude of Challenges Facing Swedish Trade Unions." In Trade Unions in Europe: Facing Challenges and Searching for Solutions, ed. Jeremy Waddington and Reiner Hoffmann. Brussels: ETUI, 529-573.

Koike, Kazuo. 1991. Shigoto no keizaigaku [Economics of Work]. Tokyo: Toyokeizaishinposha.

- 1997. Nihonkigyo no jinzaikeisei [Skill Formation in Japanese Firm]. Tokyo: Chuokoronsha.

Kume, Ikuo. 1998. Disparaged Success: Labor Politics in Postwar Japan. Ithaca, NY: Cornell University Press.

Mahon, Rianne. 1991. "From Solidaristic Wages to Solidaristic Work: A PostFordist Historical Compromise for Sweden?" Economic and Industrial Democracy 12.

Martin, Andrew. 1991. "Wage Bargaining and Swedish Politics: The Political Implications of the End of Central Negotiations." Center for European Studies Working Paper Series \#6. Harvard University.

Martin, Andrew, and George Ross, eds. 1999. The Brave New World of European Labour: Comparing Trade Unions Responses to the New European Economy. Oxford: Berghahn.

Milgrom, Paul, and John Roberts. 1992. Economics, Organization and Management. Englewood Cliff, NJ: Prentice-Hall.

Ministry of Health, Labor, and Welfare. All years. Rodokeizai Doko Chosa [Survey on Labor Economy]. Tokyo: Ministry of Health, Labor, and Welfare.

Miyamoto, Nobuchika. 1997. Nenposei no jissai [Seniority System in Practice]. Tokyo: Nihonkeizaishinbunsha.

Pontusson, Jonas. 2000. "Labor Market Institutions and Wage Distribution." In Torben Iversen, Jonas Pontusson, and David Soskice, ed. Employers Unions and Central Banks. New York: Cambridge University Press, 292-330.

Pontusson, Jonas, and Peter Swenson. 1996. "Labor Markets, Production Strategies, and Wage Bargaining Institutions: The Swedish Employer Offensive in Comparative Perspective." Comparative Political Studies 29:223-250.

Sai, Ineki. 2002. "Shinritekikeiyaku No Ihan to Jintekikanri Shsutemu [No Henkakusenryaku Breaking Psychological Contract and Strategy to Transform Human Management System]." Soshikikagaku 35:73-82.

Sako, Katsunori. 2001. Saraba itoshiki Mazda [Farewell to Mazda]. Tokyo: Bungeishunju.

Sako, M., and H. Sato, eds. 1997. Japanese Labour and Management in Transition: Diversity, Flexibility and Participation. London: Routledge and LSE.

Schulten, Thorsten. 2001. "WSI Survey Examines Decentralization of Bargaining in 1999/2000." EIROnline [cited 2001]. See <eiro.eurofound.ie/2001/03/ Feature/DE010321F.html>. 
Silvia, Stephen. 1997. "German Unification and Emerging Divisions within German Employers' Associations." Comparative Politics 29:187-208.

Skiöld, Lena. 2001. "Mediation Authority Seeks to Improve Wage Formation Process." EIROnline [cited May 2001]. See <www.eiro.eurofound.eu.int/2001/05/ feature/se0105195f.html>.

Soskice, David. 1990. "Reinterpreting Corporatism and Explaining Unemployment: Coordinated and Non-Coordinated Market Economies." In Labour Relations and Economic Performance, ed. Renato Brunetta and C. Dell'Aringa. New York: New York University Press.

Takahashi, Nobuo. 2004. Kyomou no seikashugi [Illusion of Performance-Based Management]. Tokyo: Nikkei BP.

Takewaki, Makoto, and Hirota Suyama. 2002. Gyosekikyu to Seikashugi no Kensho [Study of Performance-Based Wage and Management]. Tokyo: Dobunkan.

Thelen, Kathleen. 1991. Union of Parts: Labor Politics in Postwar Germany. Ithaca, NY: Cornell University Press.

—. 2000. "Why German Employers Cannot Bring Themselves to Dismantle the German Model." In Unions, Employers and Central Banks: Macroeconomic Coordination and Institutional Change in Social Market Economies, ed. Torben Iversen, Jonas Pontusson, and David Soskice. New York: Cambridge University Press.

- 2001. "Varieties of Labor Politics in the Developed Democracies." In Varieties of Capitalism, ed. Peter A. Hall and David Soskice. New York: Oxford University Press.

- 2002. "The Political Economy of Business and Labor in the Advanced Industrial Countries." In Political Science: The State of the Discipline, ed. Ira Katznelson and Helen V. Milner. New York and Washington, DC: Norton Books and the American Political Science Association.

Thelen, Kathleen, and Ikuo Kume. 1999. "The Effects of Globalization on Labor Revisited: Lessons from Germany and Japan." Politics $\mathcal{E}$ Society 27:476-504.

Thelen, Kathleen, and Christa van Wijnbergen. 2003. "The Paradox of Globalization: Labor Relations in Germany and Beyond." Comparative Political Studies 36:859-880.

Turner, Lowell. 1998. Fighting for Partnership: Labor and Politics in Unified Germany. Ithaca, NY: Cornell University Press.

Wallerstein, Michael, and Miriam Golden. 1997. "The Fragmentation of the Bargaining Society: Wage Setting in the Nordic Countries, 1950 to 1992." Comparative Political Studies 30:699-731.

Wallerstein, Michael, Miriam Golden, and Peter Lange. 1997. “Unions, Employers' Associations, and Wage-Setting Institutions in Northern and Central Europe, 1950-1992." Industrial and Labor Relations Review 50:379-402.

Weathers, Charles. 1999. "The 1999 Shunto and the Restructuring of Japan's Wage System." Asian Survey 39:960-985.

— 2003. “The Decentralization of Japan's Wage Setting System in Comparative Perspective." Industrial Relations Journal 34:119-134.

Yanagishita, Koichi. 2003. Kokogachigau Kachigumi Kigyo no Seikashugi [Differences in Performance-Based Management in Winner Companies]. Tokyo: Nihonkeizaishinbunsha.

Zagelmeyer, Stefan. 1997. "Collective Bargaining Coverage in Western Germany." EIROnline. See <http://www.eiro.eurofound.eu.int/1997/12/feature/ de9712140f.html>.

Zysman, John. 1996. "The Myth of a 'Global' Economy: Enduring National Foundations and Emerging Regional Realities." New Political Economy 1:157-184. 